\title{
Taxonomic recommendations for British birds: Sixth report
}

\author{
GEORGE SANGSTER,,${ }^{1,2 *}$ J. MARTIN COLLINSON,${ }^{3}$ ALAN G. KNOX, ${ }^{4}$ DAVID T. PARKIN ${ }^{5}$ \\ \& LARS SVENSSON 6 \\ ${ }^{1}$ Department of Vertebrate Zoology, Swedish Museum of Natural History, PO Box 50007, SE-104 05 \\ Stockholm, Sweden \\ ${ }^{2}$ Department of Zoology, Stockholm University, SE-106 91 Stockholm, Sweden \\ ${ }^{3}$ School of Medical Sciences, Institute of Medical Sciences, University of Aberdeen, Aberdeen AB25 2ZD, UK \\ ${ }^{4}$ Historic Collections, King's College, University of Aberdeen, Aberdeen AB24 3SW, UK \\ ${ }^{5}$ Institute of Genetics, Queen's Medical Centre, University of Nottingham, Nottingham NG7 2UH, UK \\ ${ }^{6}$ S:ta Toras väg 28, SE-260 93 Torekov, Sweden
}

This paper is the sixth report of the Taxonomic Sub-Committee of the BOU Records Committee relating to the British List. The fifth report of the Sub-Committee was published in Ibis 150: 833835.

\section{A revised taxonomic sequence of the passerines}

Since the publication of Sibley and Ahlquist (1990), numerous molecular studies have been published that have greatly expanded our knowledge of the phylogenetic relationships among passerines. A review of this literature indicates that the position of almost all major groups of passerines has been clarified. This has prompted a revision of the sequence of the passerines on the British List. The taxonomic sequence is determined based on the principle that, for each branching point in the best-supported phylogeny, the less-speciose group should be listed first. The following overview is limited to those taxa on the British List, unless otherwise indicated.

Several studies indicate that the extralimital New Zealand 'wrens' (Acanthisittidae) represent the sister-group of all other living passerines (Eupasseres), and corroborate the dichotomy between Suboscines and Oscines (Ericson et al. 2002, Barker et al. 2004, Beresford et al. 2005, Ewen et al. 2006, Chesser \& ten Have 2007, Reddy \& Cracraft 2007, Hackett et al. 2008, Irestedt et al.

*Corresponding author.

Email: george.sangster@nrm.se
2008, Yuri et al. 2008). Eastern Phoebe Sayornis phoebe is the only member of the Suboscines recorded in Great Britain, and is thus listed before all other passerines on the British List.

Among Oscines, a subdivision between Corvida and Passerida was recognized by Sibley and Ahlquist (1990). New studies have shown that Sibley and Ahlquist's 'Corvida' is a paraphyletic group composed of several African and Australasian clades (Barker et al. 2002, 2004, Ericson et al. 2002, Jønsson \& Fjeldså 2006, Driskell et al. 2007, Reddy \& Cracraft 2007). Of these clades, only Corvoidea (or 'crown Corvida') has been recorded in Britain. Corvoidea includes the vireos (Vireonidae), orioles (Oriolidae), shrikes (Laniidae), choughs, magpies, jays and crows (Corvidae) and several extralimital groups (Sibley \& Ahlquist 1990, Barker et al. 2002, 2004, Beresford et al. 2005, Fuchs et al. 2006a,b, Irestedt \& Ohlson 2008, Treplin et al. 2008). Most studies suggest that Vireonidae represents the sister-group of the other Corvoidea on the British List and that Oriolidae is sister to Laniidae and Corvidae (Barker et al. 2002, 2004, Beresford et al. 2005, Driskell et al. 2007, Reddy \& Cracraft 2007, Irestedt et al. 2008, but see Irestedt \& Ohlson 2008, Treplin et al. 2008). There is evidence that Pyrrhocorax is sister to all other British corvids (Cibois \& Pasquet 1999, Ericson et al. 2005, Ekman \& Ericson 2006, Manegold 2008), and that Nucifraga is sister to Corvus (Sibley \& Ahlquist 1990, Cibois \& Pasquet 1999, Ericson et al. 2005).

Monophyly of Passerida is supported by several studies (Sibley \& Ahlquist 1990, Ericson et al. 
2000, Barker et al. 2002, 2004, Beresford et al. 2005, Jønsson \& Fjeldså 2006, Reddy \& Cracraft 2007, Treplin et al. 2008, but see Honda \& Yamagishi 2000). Passerida (sensu Sibley \& Ahlquist 1990) consists of three major groups: Sylvioidea, Muscicapoidea and Passeroidea. Recent studies provide support for the recognition of these three groups but also demonstrate that Sibley and Ahlquist (1990) misplaced some groups (including Alaudidae, Sittidae, Certhiidae, Troglodytidae, Remizidae, Paridae). We recognize Sylvioidea, Muscicapoidea and Passeroidea but base their composition on recent studies rather than on Sibley and Ahlquist (1990) (see below). Sylvioidea represents the sister taxon of Muscicapoidea + Passeroidea (Barker et al. 2004, Beresford et al. 2005, Driskell et al. 2007, Reddy \& Cracraft 2007, Treplin et al. 2008).

The position of the kinglets (Regulus) remains unclear despite numerous studies investigating their relationships (Sheldon \& Gill 1996, Barhoum \& Burns 2002, Barker et al. 2002, 2004, Spicer \& Dunipace 2004, Beresford et al. 2005, Reddy \& Cracraft 2007, Johansson et al. 2008, Treplin et al. 2008). We place the kinglets before other Passerida as incertae sedis.

Sylvioidea (sensu Alström et al. 2006, 'core Sylvioidea' sensu Barker et al. 2002) includes the Bearded Tit (Panurus biarmicus), larks (Alaudidae), swallows (Hirundinidae), long-tailed tits (Aegithalidae) and most babblers (traditional Timaliidae) and warblers (traditional Sylviidae).

Penduline tits (Remizidae) and tits (Paridae) are resolved as the sister-group to all other Sylvioidea in some studies (Barker et al. 2004, Beresford et al. 2005, Treplin et al. 2008) but their exact position is unresolved or poorly supported in others (Sheldon \& Gill 1996, Alström et al. 2006, Johansson et al. 2008). All studies, however, are consistent with a position of penduline tits and tits close to, or among, Sylvioidea. We place the penduline tits and tits before all other Sylvioidea.

Monophyly of Sylvioidea (sensu Alström et al. 2006) is supported by numerous studies (Sheldon \& Gill 1996, Barker et al. 2004, Beresford et al. 2005, Alström et al. 2006, Driskell et al. 2007, Reddy \& Cracraft 2007, Johansson et al. 2008, Treplin et al. 2008). Panurus is neither a babbler nor a parrotbill but instead appears closely related to the larks (Ericson \& Johansson 2003, Alström et al. 2006, Fuchs et al. 2006b, Johansson et al. 2008, Gelang et al. 2009). Neither the babblers nor the warblers are monophyletic (Sheldon \& Gill 1996, Fjeldså et al. 1999, Barhoum \& Burns 2002, Barker et al. 2002, 2004, Cibois 2003, Ericson \& Johansson 2003, Beresford et al. 2005, Alström et al. 2006, Reddy \& Cracraft 2007, Johansson et al. 2008, Gelang et al. 2009). Several authors have recognized additional family taxa for groups traditionally included in Sylviidae (e.g. Dickinson 2003, Beresford et al. 2005, Alström et al. 2006, Christidis \& Boles 2008, Johansson et al. 2008, Nguembock et al. 2008). The following family taxa are adopted here (British genera in parentheses): Cettiidae (Cettia), Phylloscopidae (Phylloscopus), Sylviidae (Sylvia), Locustellidae (Locustella), Acrocephalidae (Hippolais, Acrocephalus) and Cisticolidae (Cisticola).

Muscicapoidea, as recognized here, includes the waxwings (Bombycillidae), nuthatches (Sittidae), treecreepers (Certhiidae), wrens (Troglodytidae), mockingbirds (Mimidae), starlings (Sturnidae), dippers (Cinclidae), thrushes (Turdinae), 'chats' (Saxicolini) and 'flycatchers' (Muscicapini).

The relationships of the waxwings are not yet fully clear, but almost all studies support a position among Muscicapoidea or a sister-group relationship to all other Muscicapoidea (Sibley \& Ahlquist 1990, Barker et al. 2004, Cibois \& Cracraft 2004, Voelker \& Spellman 2004, Beresford et al. 2005, Reddy \& Cracraft 2007, but see Barker et al. 2002). Waxwings are placed before all other Muscicapoidea.

Recent studies provide strong support for a clade formed by nuthatches, treecreepers, gnatcatchers (extralimital) and wrens (Sibley \& Ahlquist 1990, Sheldon \& Gill 1996, Barker et al. 2002, 2004, Ericson \& Johansson 2003, Barker 2004, Reddy \& Cracraft 2007, Johansson et al. 2008, Treplin et al. 2008). The relationships among these four groups are not yet clear but the majority of studies indicate a sister-group relationship of the nuthatches and the other three groups (Sibley \& Ahlquist 1990, Sheldon \& Gill 1996, Ericson \& Johansson 2003, Barker 2004). The relationships of the Wallcreeper Tichodroma muraria have not yet been assessed by cladistic studies, although a close relationship between Wallcreeper and Sittidae is generally accepted (e.g. Sibley \& Ahlquist 1990, Dickinson 2003).

A close relationship of the mockingbirds (Mimidae) and starlings (Sturnidae) was first proposed by Sibley and Ahlquist $(1984,1990)$ and is supported by at least 13 subsequent phylogenetic studies 
(Sheldon \& Gill 1996, Pasquet et al. 1999, Barker et al. 2002, 2004, Ericson et al. 2002, Ericson \& Johansson 2003, Cibois \& Cracraft 2004, Voelker \& Spellman 2004, Beresford et al. 2005, Reddy \& Cracraft 2007, Johansson et al. 2008, Nguembock et al. 2008, Treplin et al. 2008).

The position of the dippers is not fully resolved but most studies support a sister-group relationship of dippers and a clade comprising thrushes, chats and flycatchers (Voelker 2002, Barker et al. 2004, Cibois \& Cracraft 2004, Beresford et al. 2005, Reddy \& Cracraft 2007, Treplin et al. 2008, but see Sibley \& Ahlquist 1990, Voelker \& Spellman 2004, Fuchs et al. 2006b).

Several studies support monophyly of a group formed by thrushes, chats and flycatchers (Sibley \& Ahlquist 1990, Cibois \& Cracraft 2004, Beresford et al. 2005, Treplin et al. 2008, but see Voelker \& Spellman 2004, Fuchs et al. 2006b). Recent evidence indicates that the thrushes (Turdinae, sensu Sibley \& Monroe 1990) are not monophyletic, because some taxa (e.g. Monticola) are part of a clade formed by chats and flycatchers (Voelker \& Spellman 2004, Pan et al. 2006). Relationships among the 'true' thrushes have recently been clarified (Klicka et al. 2005, Voelker et al. 2006, Pan et al. 2007, Nylander et al. 2008, Voelker \& Klicka 2008). Numerous studies have shown that the chats (Saxicolini) are more closely related to the flycatchers (Muscicapini) than to the thrushes (Turdinae) (Sibley \& Ahlquist 1990, Chikuni et al. 1996, Pasquet et al. 1999, Barker et al. 2002, 2004, Cibois \& Cracraft 2004, Voelker \& Spellman 2004, Fuchs et al. 2006b, Treplin et al. 2008). In fact, some of these studies indicate that Saxicolini (sensu Sibley \& Ahlquist 1990) and Muscicapini (sensu Sibley \& Ahlquist 1990) are not reciprocally monophyletic (Cibois \& Cracraft 2004, Voelker \& Spellman 2004, Treplin et al. 2008). As a result of these studies, Turdinae includes Zoothera, Ixoreus, Hylocichla, Catharus and Turdus (Klicka et al. 2005), Muscicapini includes two British genera (Muscicapa and Cercotrichas), and Saxicolini includes Erithacus, Luscinia, Tarsiger, Phoenicurus, Saxicola, Oenanthe, Monticola and Ficedula (Cibois \& Cracraft 2004, Voelker \& Spellman 2004). The position of Irania has not yet been assessed with phylogenetic methods; we retain this taxon in Saxicolini.

Passeroidea (sensu Ericson et al. 2003) includes the accentors (Prunellidae), sparrows (Passeridae), wagtails and pipits (Motacillidae), chaffinches (Fringillini), finches, serins, crossbills and allies (Carduelini), snow buntings and longspurs (Calcariini), cardinals (Cardinalini), New World blackbirds and allies (Icterini), New World warblers (Parulini), Old World buntings and New World sparrows (Emberizini), and several extralimital groups.

Most studies support a sister-group relationship between the accentors (Prunellidae) and all other Passeroidea on the British List (Sorenson \& Payne 2001, Ericson \& Johansson 2003, Barker et al. 2004, Beresford et al. 2005, Johansson et al. 2008, Treplin et al. 2008, but see Sibley \& Ahlquist 1990).

A close relationship between sparrows (Passeridae) and wagtails and pipits (Motacillidae) is supported by some studies (Pasquet et al. 1999, Sorenson \& Payne 2001) but not by others (Groth 1998, Ericson et al. 2000, Barker et al. 2002, 2004, Ericson \& Johansson 2003, Johansson et al. 2008, Treplin et al. 2008). However, placement of the sparrows before wagtails and pipits, irrespective of whether they are assumed to be sister-taxa, is consistent with most studies and is adopted here. The sequence of the sparrows, and of the wagtails and pipits, adopted here, reflects the relationships inferred by Allende et al. (2001) and Voelker (1999), respectively.

There is strong evidence that Fringillidae and Emberizidae are sister-groups (Bledsoe 1988, Sibley \& Ahlquist 1990, Sorenson \& Payne 2001, Beresford et al. 2005, van der Meij et al. 2005, Treplin et al. 2008, but see Ericson \& Johansson 2003). Fringillidae consists of the genus Fringilla (Fringillini) and Carduelini. A sister-group relationship between these groups is supported in nearly all studies (Bledsoe 1988, Sibley \& Ahlquist 1990, Groth 1998, Sorenson \& Payne 2001, Yuri \& Mindell 2002, van der Meij et al. 2005), although two suggest that Carduelini is not monophyletic (Chu 2002, Treplin et al. 2008).

Emberizidae consists of six major groups: Calcariini, Cardinalini, Thraupini (extralimital), Emberizini, Icterini and Parulini. Monophyly of Emberizidae is strongly supported (Bledsoe 1988, Klicka et al. 2000, Barker et al. 2002, Yuri \& Mindell 2002, Ericson \& Johansson 2003). The snow buntings and longspurs form a clade that is distinct from all other buntings (Klicka et al. 2000, 2003, 2007, Grapputo et al. 2001, Lovette \& Bermingham 2002, Yuri \& Mindell 2002, Carson \& Spicer 
2003, Ericson \& Johansson 2003, Alström et al. 2008). The name Calcariini is adopted for this group. Current evidence indicates that Plectrophenax is nested in Calcarius (sensu AOU 1998, Dickinson 2003) and that the latter is not monophyletic (Klicka et al. 2003, 2007). However, we do not merge Plectrophenax and Calcarius in one genus as suggested by Klicka et al. (2003), but propose to reinstate the monotypic genus Rhynchophanes for the extralimital McCown's Longspur Calcarius mccownii. As a consequence, the name Plectrophenax is retained for the snow buntings.

The relationships among the remaining groups (Cardinalini, Thraupini, Emberizini, Icterini and Parulini) are unclear due to conflicting results of phylogenetic studies. For instance, Cardinalini and Thraupini are supported as sister-taxa in some analyses (Bledsoe 1988, Barker et al. 2002, Yuri \& Mindell 2002, Klicka et al. 2003, 2007) but not in others (Sibley \& Ahlquist 1990, Klicka et al. 2000, Lovette \& Bermingham 2002). Icterini and Parulini are resolved as sister-groups by some studies (Bledsoe 1988, Barker et al. 2002, Ericson \& Johansson 2003) but not by all (Sibley \& Ahlquist 1990, Klicka et al. 2000, 2003, 2007, Yuri \& Mindell 2002).

Several studies indicate that the 'tanager' genus Piranga is actually part of the cardinal clade (Lovette \& Bermingham 2002, Yuri \& Mindell 2002, Burns et al. 2003, Klicka et al. 2003, 2007, Alström et al. 2008). The two species of Piranga on the British List (Summer Tanager P. rubra and Scarlet Tanager $P$. olivacea) are therefore placed in Cardinalini. Consequently, no member of the Thraupini is admitted on the British List.

It is doubtful whether Emberizini represents a monophyletic group. New World 'sparrows' and Old World 'buntings' form separate clades (Grapputo et al. 2001, Lovette \& Bermingham 2002, Klicka et al. 2003, 2007, Alström et al. 2008). Several studies suggest that Old World and New World groups are not sister taxa (Lovette \& Bermingham 2002, Klicka et al. 2003, Alström et al. 2008, but see Klicka et al. 2007). Relationships among Old World buntings have recently been clarified (Alström et al. 2008). Relationships among New World sparrows have been more intensively studied, but no consensus has emerged (e.g. Avise et al. 1980a, Zink \& Blackwell 1996, Patten \& Fugate 1998, Carson \& Spicer 2003, Klicka et al. 2007, DaCosta et al. 2009). The sequence of the species in these groups is left unchanged.
A phylogenetic study of Icterini has identified five major clades (Lanyon \& Omland 1999, see also Freeman \& Zink 1995). However, as the relationships among these clades are unresolved, the taxonomic sequence is left unchanged.

Phylogenetic studies indicate that the New World warblers (sensu AOU 1998) are not monophyletic (Lovette \& Bermingham 2002, Klein et al. 2004). However, all species on the British List are part of a well-supported clade consisting of 19 genera of morphologically typical parulids (Lovette \& Bermingham 2002). Several traditionally accepted genera are not monophyletic (Avise et al. 1980b, Lovette \& Bermingham 2001, 2002, Klein et al. 2004, Lovette \& Hochachka 2006); a comprehensive revision of Parulidae is warranted.

The sequence of the passerines on the British List (including those that are not currently part of the British List but which reside in Category D) becomes as follows:

\author{
Suboscines \\ Tyrannides \\ Tyrannidae (Sayornis) \\ Oscines \\ Corvida \\ Corvoidea \\ Vireonidae (Vireo) \\ Oriolidae (Oriolus) \\ Laniidae (Lanius) \\ Corvidae (Pyrrhocorax, Pica, Garrulus, \\ Nucifraga, Corvus) \\ Passerida \\ Regulidae (Regulus) incertae sedis \\ Sylvioidea \\ Remizidae (Remiz) \\ Paridae (Cyanistes, Parus, Lophophanes, Peri- \\ parus, Poecile) \\ Panuridae (Panurus) \\ Alaudidae (Melanocorypha, Calandrella, \\ Galerida, Lullula, Alauda, Eremophila) \\ Hirundinidae (Riparia, Tachycineta, Progne, \\ Ptyonoprogne, Hirundo, Delichon, Cecropis, \\ Petrochelidon) \\ Cettiidae (Cettia) \\ Aegithalidae (Aegithalos) \\ Phylloscopidae (Phylloscopus) \\ Sylviidae (Sylvia) \\ Locustellidae (Locustella) \\ Acrocephalidae (Hippolais, Acrocephalus)
}




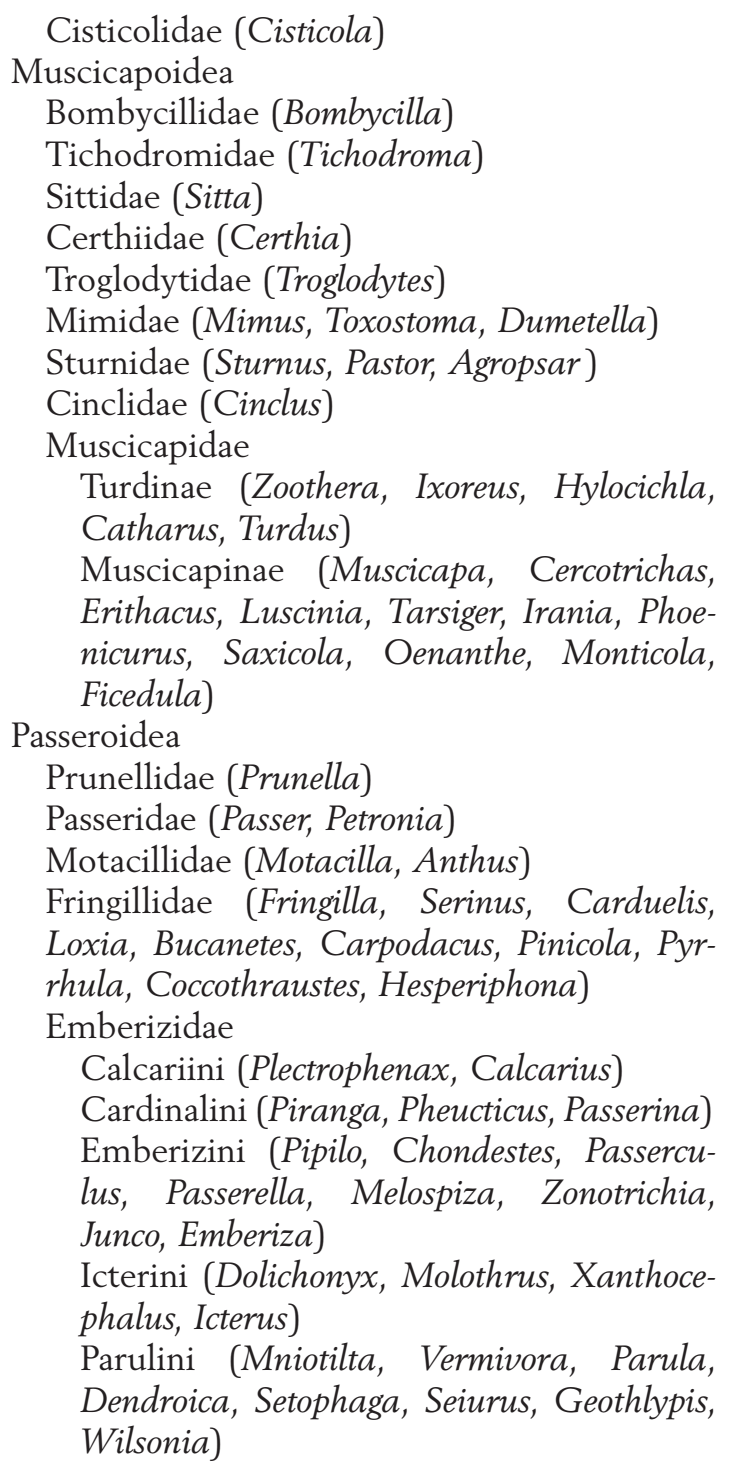

We are grateful to Per Alström and Per Ericson for reading an early version of this report.

\section{REFERENCES}

Allende, L.M., Rubio, I., Ruiz-Del-Valle, V., Guillen, J., Martinez-Laso, J., Lowy, E., Varela, P., Zamora, J. \& Arnaiz-Villena, A. 2001. The Old World sparrows (genus Passer) phylogeography and their relative abundance of nuclear mtDNA pseudogenes. J. Mol. Evol. 53: 144-154.

Alström, P., Ericson, P.G.P., Olsson, U. \& Sundberg, P. 2006. Phylogeny and classification of the avian superfamily Sylvioidea, based on nuclear and mitochondrial sequence data. Mol. Phylogenet. Evol. 38: 381-397.

Alström, P., Olsson, U., Lei, F., Wang, H.-T., Gao, W. \& Sundberg, P. 2008. Phylogeny and classification of the Old
World Emberizini (Aves, Passeriformes). Mol. Phylogenet. Evol. 47: 960-973.

American Ornithologists' Union (AOU) 1998. Check-List of North American Birds, 7th edn. Washington, DC: American Ornithologists' Union.

Avise, J.C., Patton, J.C. \& Aquadro, C.F. 1980a. Evolutionary genetics of birds. II. Conservative protein evolution in North American sparrows and relatives. Syst. Zool. 29: 323-334.

Avise, J.C., Patton, J.C. \& Aquadro, C.F. 1980b. Comparative molecular evolution in New World warblers (Parulidae) and rodents (Cricetidae). J. Hered. 71: 303-310.

Barhoum, D.N. \& Burns, K.J. 2002. Phylogenetic relationships of the Wrentit based on mitochondrial cytochrome $b$ sequences. Condor 104: 740-749.

Barker, F.K. 2004. Monophyly and relationships of wrens (Aves: Troglodytidae): a congruence analysis of heterogeneous mitochondrial and nuclear DNA sequence data. Mol. Phylogenet. Evol. 31: 486-504.

Barker, F.K., Barrowclough, G. \& Groth, J.G. 2002. A phylogenetic hypothesis for passerine birds: taxonomic and biogeographic implications of an analysis of nuclear DNA sequence data. Proc. R. Soc. Lond. B 269: 295-308.

Barker, F.K., Cibois, A., Schikler, P., Feinstein, J. \& Cracraft, J. 2004. Phylogeny and diversification of the largest avian radiation. Proc. Natl Acad. Sci. USA 101: 11040-11045.

Beresford, P., Barker, F.K., Ryan, P.G. \& Crowe, T.M. 2005. African endemics span the tree of songbirds (Passeri): molecular systematics of several evolutionary 'enigmas'. Proc. R. Soc. Lond. B 272: 849-858.

Bledsoe, A.H. 1988. Nuclear DNA evolution and phylogeny of the New World nine-primaried oscines. Auk 105: 504515.

Burns, K.J., Hackett, S.J. \& Klein, N.K. 2003. Phylogenetic relationships of Neotropical honeycreepers and the evolution of feeding morphology. J. Avian Biol. 34: 360-370.

Carson, R.J. \& Spicer, G.S. 2003. A phylogenetic analysis of the emberizid sparrows based on three mitochondrial genes. Mol. Phylogenet. Evol. 29: 43-57.

Chesser, R.T. \& ten Have, J. 2007. On the phylogenetic popition of the scrub-birds (Passeriformes: Menurae: Atrichornithidae) of Australia. J. Ornithol. 148: 471-476.

Chikuni, K., Minaka, N. \& Ikenaga, H. 1996. Molecular phylogeny of some Passeriformes, based on cytochrome b sequences. J. Yamashina Inst. Ornithol. 28: 1-8.

Christidis, L. \& Boles, W.E. 2008. Systematics and Taxonomy of Australian Birds. Collingwood, Victoria: CSIRO Publishing.

Chu, P.C. 2002. A morphological test of the monophyly of the cardueline finches (Aves: Fringillidae, Carduelinae). Cladistics 18: 279-312.

Cibois, A. 2003. Mitochondrial DNA phylogeny of babblers (Timaliidae). Auk 120: 35-54.

Cibois, A. \& Cracraft, J. 2004. Assessing the passerine 'Tapestry': phylogenetic relationships of the Muscicapoidea inferred from nuclear DNA sequences. Mol. Phylogenet. Evol. 32: 264-273.

Cibois, A. \& Pasquet, E. 1999. Molecular analysis of the phylogeny of 11 genera of the Corvidae. Ibis 141: 297-306.

DaCosta, J.M., Spellman, G.M., Escalante, P. \& Klicka, J. 2009. A molecular systematic revision of two historically 
problematic songbird clades: Aimophila and Pipilo. J. Avian Biol. 40: 206-216.

Dickinson, E.C. 2003. The Howard and Moore Complete Checklist of the Birds of the World, 3rd edn. London: Christopher Helm

Driskell, A., Christidis, L., Gill, B.J., Boles, W.E., Barker, F.K. \& Longmore, N.W. 2007. A new endemic family of New Zealand passerine birds: adding heat to a biodiversity hotspot. Aust. J. Zool. 55: 73-78.

Ekman, J. \& Ericson, P.G.P. 2006. Out of Gondwanaland; the evolutionary history of cooperative breeding and social behaviour among crows, magpies, jays and allies. Proc. $R$. Soc. Lond. B 273: 1117-1125.

Ericson, P.G.P. \& Johansson, U.S. 2003. Phylogeny of Passerida (Aves: Passeriformes) based on nuclear and mitochondrial sequence data. Mol. Phylogenet. Evol. 29: 126-138.

Ericson, P.G.P., Johansson, U.S. \& Parsons, T.J. 2000. Major divisions of oscines revealed by insertions in the nuclear gene c-myc: A novel gene in avian phylogenetics. Auk 117: 1077-1086.

Ericson, P.G.P., Christidis, L., Cooper, A., Irestedt, M., Jackson, J., Johansson, U.S. \& Norman, J.A. 2002. A Gondwanan origin of passerine birds supported by DNA sequences of the endemic New Zealand wrens. Proc. $R$. Soc. Lond. B 269: 235-241.

Ericson, P.G.P., Irestedt, M. \& Johansson, U.S. 2003. Evolution, biogeography, and patterns of diversification in passerine birds. J. Avian Biol. 34: 3-15.

Ericson, P.G.P., Jansén, A.-L., Johansson, U.S. \& Ekman, J. 2005. Inter-generic relationships of the crows, jays, magpies and allied groups (Aves: Corvidae) based on nucleotide sequence data. J. Avian Biol. 36: 222234.

Ewen, J.G., Flux, I. \& Ericson, P.G.P. 2006. Systematic affinities of two enigmatic New Zealand passerines of high conservation priority, the Hihi or Stitchbird Notiomystis cincta and the Kokako Callaeas cinerea. Mol. Phylogenet. Evol. 40: 281-284.

Fjeldså, J., Goodman, S.M., Schulenberg, T.S. \& Slikas, B. 1999. Molecular evidence for relationship of Malagasy birds. Proc. Int. Ornithol. Congr. 22: 3084-3094.

Freeman, S. \& Zink, R.M. 1995. A phylogenetic study of the blackbirds based on variation in mitochondrial DNA restriction sites. Syst. Biol. 44: 409-420.

Fuchs, J., Fjeldså, J. \& Pasquet, E. 2006a. An ancient African radiation of corvoid birds (Aves: Passeriformes) detected by mitochondrial and nuclear sequence data. Zool. Scr. 35: 375-385.

Fuchs, J., Fjeldså, J., Bowie, R.C.K., Voelker, G. \& Pasquet, E. 2006b. The African warbler genus Hyliota as a lost lineage in the oscine songbird tree: molecular support for an African origin of the Passerida. Mol. Phylogenet. Evol. 39: 186-197.

Gelang, M., Cibois, A., Pasquet, E., Olsson, U., Alström, P. \& Ericson, P.G.P. 2009. Phylogeny of babblers (Aves, Passeriformes): major lineages, family limits and classification. Zool. Scr. 38: 225-236.

Grapputo, A., Pilastro, A., Baker, A.J. \& Marin, G. 2001. Molecular evidence for phylogenetic relationships among buntings and American sparrows (Emberizidae). J. Avian Biol. 32: 95-101.
Groth, J.G. 1998. Molecular phylogenetics of finches and sparrows: consequences of character removal in cytochrome b sequences. Mol. Phylogenet. Evol. 10: 377-390.

Hackett, S.J., Kimball, R.T., Reddy, S., Bowie, R.C.K., Braun, E.L., Braun, M.J., Chojnowski, J.L., Cox, W.A., Han, K.-L., Harshman, J., Huddleston, C.J., Marks, B.D., Miglia, K.J., Moore, W.S., Sheldon, F.H., Steadman, D.W., Witt, C.C. \& Yuri, T. 2008. A phylogenomic study of birds reveals their evolutionary history. Science 320: 1763-1768.

Honda, M. \& Yamagishi, S. 2000. A molecular perspective on oscine phylogeny, with special reference to inter-familial relationships. Jap. J. Ornithol. 49: 175-184.

Irestedt, M. \& Ohlson, J.I. 2008. The division of the major songbird radiation into Passerida and 'core Corvoidea' (Aves: Passeriformes) - the species tree vs. gene trees. Zool. Scr. 37: 305-313.

Irestedt, M., Fuchs, J., Jønsson, K.A., Ohlson, J.I., Pasquet, E. \& Ericson, P.G.P. 2008. The systematic affinity of the enigmatic Lamprolia victoriae (Aves: Passeriformes) an example of avian dispersal between New Guinea and Fiji over Miocene intermittent land bridges? Mol. Phylogenet. Evol. 48: 1218-1222.

Johansson, U.S., Fjeldså, J. \& Bowie, R.C.K. 2008. Phylogenetic relationships within Passerida (Aves: Passeriformes): a review and a new molecular phylogeny based on three nuclear intron markers. Mol. Phylogenet. Evol. 48: 858-876.

Jønsson, K.A. \& Fjeldså, J. 2006. A phylogenetic supertree of oscine passerine birds (Aves: Passeri). Zool. Scr. 35: 149-186.

Klein, N.K., Burns, K.J., Hackett, S.J. \& Griffiths, C.S. 2004. Molecular phylogenetic relationships among the wood warblers (Parulidae) and historical biogeography in the Caribbean basin. J. Caribb. Ornithol. 17: 3-17.

Klicka, J., Johnson, K.P. \& Lanyon, S.M. 2000. New World nine-primaried oscine relationships: constructing a mitochondrial DNA framework. Auk 117: 321-336.

Klicka, J., Zink, R.M. \& Winker, K. 2003. Longspurs and Snow Buntings: phylogeny and biogeography of a high-latitude clade (Calcarius). Mol. Phylogenet. Evol. 26: 165-175.

Klicka, J., Voelker, G. \& Spellman, G.M. 2005. A molecular phylogenetic analysis of the 'true thrushes' (Aves: Turdinae). Mol. Phylogenet. Evol. 34: 486-500.

Klicka, J., Burns, K. \& Spellman, G.M. 2007. Defining a monophyletic Cardinalini: a molecular perspective. Mol. Phylogenet. Evol. 45: 1014-1032.

Lanyon, S.M. \& Omland, K.E. 1999. A molecular phylogeny of the blackbirds (Icteridae): five lineages revealed by cytochrome-b sequence data. Auk 116: 629-639.

Lovette, I.J. \& Bermingham, E. 2001. A mitochondrial sequence-based phylogenetic analysis of Parula woodwarblers (Aves: Parulidae). Auk 118: 211-215.

Lovette, I.J. \& Bermingham, E. 2002. What is a woodwarbler? Molecular characterization of a monophyletic Parulidae. Auk 119: 695-714.

Lovette, I.J. \& Hochachka, W.M. 2006. Simultaneous effects of phylogenetic niche conservatism and competition on avian community structure. Ecology 87: S14-S28.

Manegold, A. 2008. Morphological characters of the tongue skeleton reveal phylogenetic relationships within Corvidae (Oscines, Passeriformes). Emu 108: 321-330.

van der Meij, M.A.A., de Bakker, M.A.G. \& Bout, R.G. 2005. Phylogenetic relationships of finches and allies based on 
nuclear and mitochondrial DNA. Mol. Phylogenet. Evol. 34: 97-105.

Nguembock, B., Fjeldså, J., Cruaud, C. \& Pasquet, E. 2008. Molecular phylogenetic analysis of all members of the genus Elminia confirms their presence within the Stenostiridae clade. Zool. Scr. 37: 591-602.

Nylander, J.A.A., Olsson, U., Alström, P. \& Sanmartín, I. 2008. Accounting for phylogenetic uncertainty in biogeography: a Bayesian approach to dispersal-vicariance analysis of the thrushes (Aves: Turdus). Syst. Biol. 57: 257268.

Pan, Q.-W., Lei, F.-M., Yang, S.-J., Yin, Z.-H., Huang, Y., Tai, F.-D. \& Kristin, A. 2006. Phylogenetic analysis of some Turdinae birds based on mitochondrial cytochrome $b$ gene sequences. Acta Zool. Sin. 52: 87-98.

Pan, Q.-W., Lei, F.-M., Yin, Z.-H., Kristin, A. \& Kanuch, P. 2007. Phylogenetic relationships between Turdus species: mitochondrial cytochrome b gene analysis. Ornis Fenn. 84: $1-11$.

Pasquet, E., Cibois, A., Baillon, F. \& Erard, C. 1999. Relationships between Ant-thrushes Neocossyphus and the Flycatcher-thrushes Stizorhina, and their position relative to Myadestes, Entomodestes and some other Turdidae (Passeriformes). J. Zool. Syst. Evol. Res. 37: 177-183.

Patten, M.A. \& Fugate, M. 1998. Systematic relationships among the emberizid sparrows. Auk 115: 412-424.

Reddy, S. \& Cracraft, J. 2007. Old World shrike-babblers (Pteruthius) belong with New World vireos (Vireonidae). Mol. Phylogenet. Evol. 44: 1352-1357.

Sheldon, F.H. \& Gill, F.B. 1996. A reconsideration of songbird phylogeny, with emphasis on the evolution of Titmice and their sylvioid relatives. Syst. Biol. 45: 473-495.

Sibley, C.G. \& Ahlquist, J.E. 1984. The relationships of the starlings (Sturnidae: Sturnini) and the mockingbirds (Sturnidae: Mimini). Auk 101: 230-243.

Sibley, C.G. \& Ahlquist, J.E. 1990. Phylogeny and Classification of Birds. New Haven, CT: Yale University Press.
Sibley, C.G. \& Monroe, B.L. 1990. Distribution and Taxonomy of Birds of the World. New Haven, CT: Yale University Press.

Sorenson, M.D. \& Payne, R.B. 2001. A single ancient origin of brood parasitism in African finches: implications for hostparasite coevolution. Evolution 55: 2550-2567.

Spicer, G.S. \& Dunipace, L. 2004. Molecular phylogeny of songbirds (Passeriformes) inferred from mitochondrial 16S ribosomal RNA gene sequences. Mol. Phylogenet. Evol. 30: 325-335.

Treplin, S., Siegert, R., Bleihorn, C., Thompson, H.S., Fotso, R. \& Tiedemann, R. 2008. Molecular phylogeny of songbirds (Aves: Passeriformes) and the relative utility of common nuclear marker loci. Cladistics 24: 328-349.

Voelker, G. 1999. Molecular evolutionary relationships in the avian genus Anthus (Pipits: Motacillidae). Mol. Phylogenet. Evol. 11: 84-94.

Voelker, G. 2002. Molecular phylogenetics and the historical biogeography of dippers (Cinclus). Ibis 144: 577-584.

Voelker, G. \& Klicka, J. 2008. Systematics of Zoothera thrushes, and a synthesis of true thrush molecular systematic relationships. Mol. Phylogenet. Evol. 49: 377-381.

Voelker, G. \& Spellman, G.M. 2004. Nuclear and mitochondrial DNA evidence of polyphyly in the avian superfamily Muscicapoidea. Mol. Phylogenet. Evol. 30: 386-394.

Voelker, G., Rohwer, S., Bowie, R.C.K. \& Outlaw, D.C. 2006. Molecular systematics of a speciose, cosmopolitan songbird genus: defining the limits of, and relationships among, the Turdus thrushes. Mol. Phylogenet. Evol. 42: 422-434.

Yuri, T. \& Mindell, D.P. 2002. Molecular phylogenetic analysis of Fringillidae, 'New World nine-primaried oscines' (Aves: Passeriformes). Mol. Phylogenet. Evol. 23: 229-243.

Yuri, T., Kimball, R.T., Braun, E.L. \& Braun, M.J. 2008. Duplication of accelerated evolution and growth hormone gene in passerine birds. Mol. Biol. Evol. 25: 352-361.

Zink, R.M. \& Blackwell, R.C. 1996. Patterns of allozyme, mitochondrial DNA, and morphometric variation in four sparrow genera. Auk 113: 59-67. 